\title{
LIFELONG EDUCATION PROGRAMS IN HUMAN RESOURCE CAPACITY DEVELOPEMENT FOR THE NEEDS OF MANAGEMENT IN EVENTS OF CRISES
}

\author{
Admir Hadžikadunić, PhD \\ Faculty of Criminal Justice, Criminology and Security Studies - \\ E-mail: ahadzikadunic@fkn.unsa.ba
}

\section{Abstract}

Security challenges of nowadays which are manifested through terrorist attacks, armed conflicts, economic and armed warfare, lead to great population migrations from the vulnerable areas. To successfully manage migrations and other crises, it is necessary to integrate new knowledges along with constant changes in skill profiles, qualifications and experiences. The skill lack of people employed in government and non-government agencies for crisis management, as well as their incompatibility and inflexibility, can lead to unwanted events. Lifelong education programs of higher education institutions have become an everyday practice in many European, and world universities. The goal of such acyclic academic programs is the exchange of knowledge and experience through organization of special programs, or courses, in different areas in cooperation with various faculties and universities. Such programs are intended for students, professionals or other individuals who want to inform themselves, evolve and develop their skills, knowledge and competences in certain areas. The concept of lifelong education originates from everyday increase in new, and the fast obsolescence of old knowledge. Moreover, lifelong education is based on constant approach to learning and education. Gaining new and renewing old skills and knowledge is necessary to participate in a learning society. Therefore, lifelong education means education through schooling, but also through various forms of informal education such as courses, additional training, retraining and professional development. It is a process of constant development and increase in knowledge gained through a formal education system, with the goal to perfect existing skills, gain new knowledges, and modern qualifications. Lifelong education implies to the integration of formal, non-formal and informal learning, to gain the opportunity for constant development of life quality. Formal education is directed from teachers or instructors and is gained in educational institutions according to lesson plans and programs approved by competent institutions. Non-formal education is an organized form of learning and education directed towards perfecting, specialization and replenishment of skills, knowledges and abilities, 


\section{Secuurity}

according to special programs performed by education organizers. Informal learning stands for unplanned knowledge acquisition through everyday activities.

Key words: Security threats, management in events of crises, competences, skills, lifelong education programs.

\section{Introduction}

Nowadays, when security threats are more frequent due to ethnic divisions, economic wars and terrorist attacks, the need for management in events of crises occurs. Terrorist attacks, migration crises which have become more frequent in Europe, reflect negatively on countries of the Western Balkans as well. For Western Balkans countries to successfully manage new crises, it is necessary to integrate new jobs with continuous profile, skill, qualification and experience changes, into the staff education system for crisis event needs.

The skill lack of people employed in government and non-government agencies for crisis management, as well as their incompatibility and inflexibility can lead to unwanted situations. Accordingly, the security sector must argue about "lifelong education"56, with a goal to exchange experiences and good practices that will ultimately develop skills, abilities and knowledge of human resources necessary to manage new crises. The term lifelong education prevailed on a meeting in Paris, 1996, when 25 ministers of education from Western and Central Europe, Australia, Canada, Japan, Mexico, New Zealand and USA concluded that a paradigmatic turnover would be realized from "education towards learning", which is necessary as a primary goal of the education reform in the word. Also, one conclusion was that "lifelong education for everyone" should be the leading principle of future education policy (Paustović, 2008).

People, as the main idea and holders of information, new skill and abilities, become a strategic base for the development of contemporary security concepts for crisis management. Investments into human resource quality are a primary factor for the development of the security sector, while the education system must be adjusted and offer a possibility for retraining and additional training.

The education systems in Bosnia and Herzegovina, along with regional countries, need to raise demands for education, and its offers as well. So far, formal education in Bosnia and Herzegovina and region, exclusively determined the policy and way of gaining knowledge. The society of nowadays is a society of knowledge, an information, pluralistic, innovative society with a multicultural character which seeks new and different means of work and achieving success, and

\footnotetext{
${ }^{56}$ Lifelong education is a concept which includs all citizens in formal education programs, as wel as Unintentional, unorganized and spontaneous knowledge, skill and opinion acquisition (competences) can be conducted in a non-formal and informal way during the whole life, next to mandatory and other forms of regular education
} 
if we want to be an active part of such a society, we must accept changes, adapt quickly, change the ways of learning and working, i.e., keep in step with time.

The contemporary education strategy is based on the principle of lifelong education. Induced by the fact that the amount of new knowledge increases with great speed, and knowledge acquired with traditional education (formal education), it becomes outdated and stops satisfying the needs of individuals and society as well. One of the processes to affirm lifelong education is the establishment of a system to acknowledge acquired knowledge and skills derived from informal learning methods, what enables a bigger vertical mobility and flexibility by applying the principles of lifelong learning, what is predicted by the qualification frame and strategic EU documents.

The European Commission stated that current, and future, EU member states, have to develop flexible and clear ways of lifelong learning implementation, and adult education with the goal to increase employment in the labour market. Because of that, it is important to adapt the working structure with education programs, contemporary qualifications, professions and the labour market. Next to competence acquisition for qualifications and professions, the adaption to social and economic changes in the surroundings is becoming more and more important. ${ }^{57}$ Lifelong education is a concept which promotes the making, refurbishment, and application of newly acquired knowledge, skills and opinions. Recommendations of the European Commission "Making a European Area of Lifelong Learning a Reality (2001) ${ }^{58}$ and the EU Council Resolution on Lifelong Learning (2002) ${ }^{59}$ highlights the needs to transform traditional education systems, make them more open and flexible so students can develop individual learning ways according to their needs and interests.

Key implications of the lifelong education concept, or lifelong learning, are the change in understanding education as schooling and abandonment of traditional beliefs that education is meant only for children and young people, not adults. Lifelong learning expands the concept of education with the schooling of young people (and adults) to a non-formal and informal education of adults and includes the experiential learning of young people and adults. For the development of the lifelong education, or lifelong learning, concept, elucidation of the world education crisis had a crucial influence (Coombs, 1968). The education crisis manifested in an increasing gap between material and human inputs into education and realized outputs and effects of education on the economic and social development. Coombs explained the crisis through the fact that the rigid organization of expensive and intensive school system is inappropriate to satisfy new educational needs which occur in economic, political and sociocultural surroundings of a constantly changing education. The exit from this education crisis Coombs sees in non-formal education.

\footnotetext{
${ }^{57}$ Commission of the European Communities Brussels, 2006. Communication from the Commission to the Council and to the European Parliament: Efficiency and equity in European education and training systems, Brussels: Commission of the European Communities.

${ }^{58} \mathrm{http}$ ://eur-lex.europa.eu/LexUriServ/LexUriServ.do?uri=COM:2001:0678:FIN:EN:PDF

${ }^{59}$ http://eur-lex.europa.eu/LexUriServ/LexUriServ.do?uri=0J:C:2002:163:0001:0003:EN:PDF
} 


\section{Forms of lifelong learning}

Forms of lifelong learning can be divided according to next criteria: degree of organization, structure, and conditions in which education occurs (space, equipment, books, teacher qualifications, learning methods, knowledge functionality, skills, opinions, and the certification degree of education outcomes. Ordered by such criteria, lifelong learning forms are: formal education, non-formal education and informal education. Unintentional learning is experiential learning. Experiential learning is not organized or structured.

According to International Standard Classification of Education (2000.) formal education is conducted in a system of schools, universities and other formal institutions which often make an uninterrupted ladder of education degrees. It usually occurs in ages from five to seven years, and full-time which usually lasts from 20 to 25 years. Higher education degrees can be conducted as education with work (part-time). Formal education results with a diploma for the finished education degree.

Non-formal education is, according to Dohmen, every type of organized learning not leading to a diploma which acknowledges a certain education degree. According to International Standard Classification of education (2000), non-formal education is a systematically organized education activity which can be conducted in school and non-school institutions, and includes individuals of every age group, from children to people in their third life span. Finishing a form of non-formal education can result with a certificate of successful accomplishment of the same, but it does not result with a certain qualification degree. There are different organizational forms of non-formal education like: seminars, courses, consultations, symposiums, conferences, summer, winter schools and other.

Informal education is a form of intentional learning which is less organized than non-formal education. Non-formal education is organized by institutions and individuals for the needs of other persons which will study with their help. Informal education is initiated and organized by the individual, who will learn without any external help from others - it is not organized from the outside. Self-education can be completely independent (the individual independently determines the goal of his studies, plans, organizes and evaluates the results of his learning) or can ask for certain help from other individuals and institutions (Matković, Poljak, 1989).

Learning forms are combined in lifelong education, or lifelong learning, implementation. Lifelong learning does not replace traditional education, what was believed to be possible in the beginning, and preferable because of the lack of education than the flexible learning system which provides lifelong acquisition and development of competences necessary for people in their adult ages. As the lifelong learning phases are connected, the application of lifelong learning concept requires a reinterpretation of schooling, along with education for adults which earlier existed as a parallel education system independent of schooling (Pastuović, 2008). 


\section{Contents of the paper}

\section{Lifelong learning program evaluation}

The Faculty of Criminal Justice, Criminology and Security Studies at the University in Sarajevo, recognized the importance of lifelong learning as a very flexible and adaptable learning forms, and in 2015 , started lifelong education programs through summer and winter schools.

The methodology of lesson plan and lifelong learning program creation of the Faculty of Criminal Justice, Criminology and Security Studies, as well as implementation of the same through forms of acyclic academic programs, winter and summer schools, start from an established general strategy of social development, especially modern education policies and verified pedagogical standards with competence expectations. To the creation of lesson plans and acyclic academic programs on the Faculty of Criminal Justice, Criminology and Security Studies it is approached in a way to incorporate formal, non-formal and informal learning into the program contents, together with programs of media inculturation and socialization. Optimal, rational and interdisciplinary content are a basic guide when creating lesson plans and lifelong learning programs. Also, as a very important principle when developing lesson plans and lifelong education programs is the complexity to set clear goals and assignments of lifelong education as a curricular starting point.

In order to successfully implement the created lesson plan and lifelong education program, we have set guidelines and implementation teams. The organization structure of international summer and winter schools is defined in the document: Partnership protocol in organization of the International Summer School. The mentioned document confirms that international winter and summer schools are manage by the Expert Council of the school, which consists of members delegated from every partner. The Expert Council is composed of faculty deans, vice deans for education, vice deans for international cooperation, appointed school hosts, and school coordinators. Every decision regarding the summer and winter schools is made by the Expert Council consensus. With the goal of expeditious work, the Expert Council of the summer or winter schools can make and confirm their decisions via e-mail or video correspondence and must meet at least two times during preparation for the project activities preparation.

Teams for curriculum and acyclic academic lifelong learning program implementation, of the summer and winter school, on the Faculty of Criminal Justice, Criminology and Security Studies coordinate and manage the processes of making and implementation of curriculums to avoid problems in the realization of school activities. Even if such problems occur during the activity implementation, the task of the teams is to engage additional necessary resources to avoid market changes which can alter the attractiveness of winter and summer schools. ${ }^{60}$ Errors in market evaluation are another possible risk factor which can influence the market not to accept offered curriculums. To avoid such a risk, the team for curriculum development of the winter

\footnotetext{
${ }^{60}$ For direct and end users (in market change, one of the risk factors for implementation of summer and winter schools are activities of other organizations which realize similar programs).
} 
and summer schools, evaluates and consults all government and non-government organizations whose activities are related to summer and winter school programs, and in that way, provide the market (final users) with an acceptable final product (curriculum).

Winter and summer school programs as a lifelong education organization form are realized through an interdisciplinary approach from different areas which have prevention and management in the events of new crises as a final goal. Summer school programs, which the Faculty of Criminal Justice, Criminology and Security Studies successfully realized in the period of 2015 to 2018 are:

\section{Summer School - Treatment guidelines in the case of child violence in Bosnia and Herzegovina}

This program of lifelong learning was attended by 63 participants, directors and assistant directors of elementary and high schools, teachers, pedagogues, psychologists, employees at departments of social work across FBiH and students from the University in Sarajevo. The goal of this program is to enable participants to apply the gained knowledge in the events of child violence, through elements of law awareness, acts and protocols in Bosnia and Herzegovina, knowledge in phenomenology of child violence, systems of early child violence recognition, treatment guidelines in specific sectors. Partners in realization of this program were UNICEF BiH, "Save the Children", Cantonal Centre for Social Work Sarajevo", Sarajevo elementary school director association ${ }^{61}$. Summer school evaluation, from 63 participants, consisted of 9 questions which should evaluate the organization quality and program of this summer school. The given questions could be rated in range from 1 to 5 . The questions were related to next summer school aspects: Summer school organization was rated with 5, 61; Usefulness of practical examples with 4, 29; Quality and availability of prepared materials with 4,65; Usage of technical aids with 4.60; Lecture timelines with 4,54; Presentation successfulness of lecturers with 4,36, while lecturer interaction was rated with 4,65 . With the total summer school rating of 4, 50, we can conclude that the participants were very satisfied with the method of program content implementation.

${ }^{61}$ http://criminaleast.fkn.unsa.ba/index.php/edukacija 
Graph No.1 - Evaluation of the lifelong learning program - Summer School - Treatment guidelines in the case of child violence in Bosnia and Herzegovina

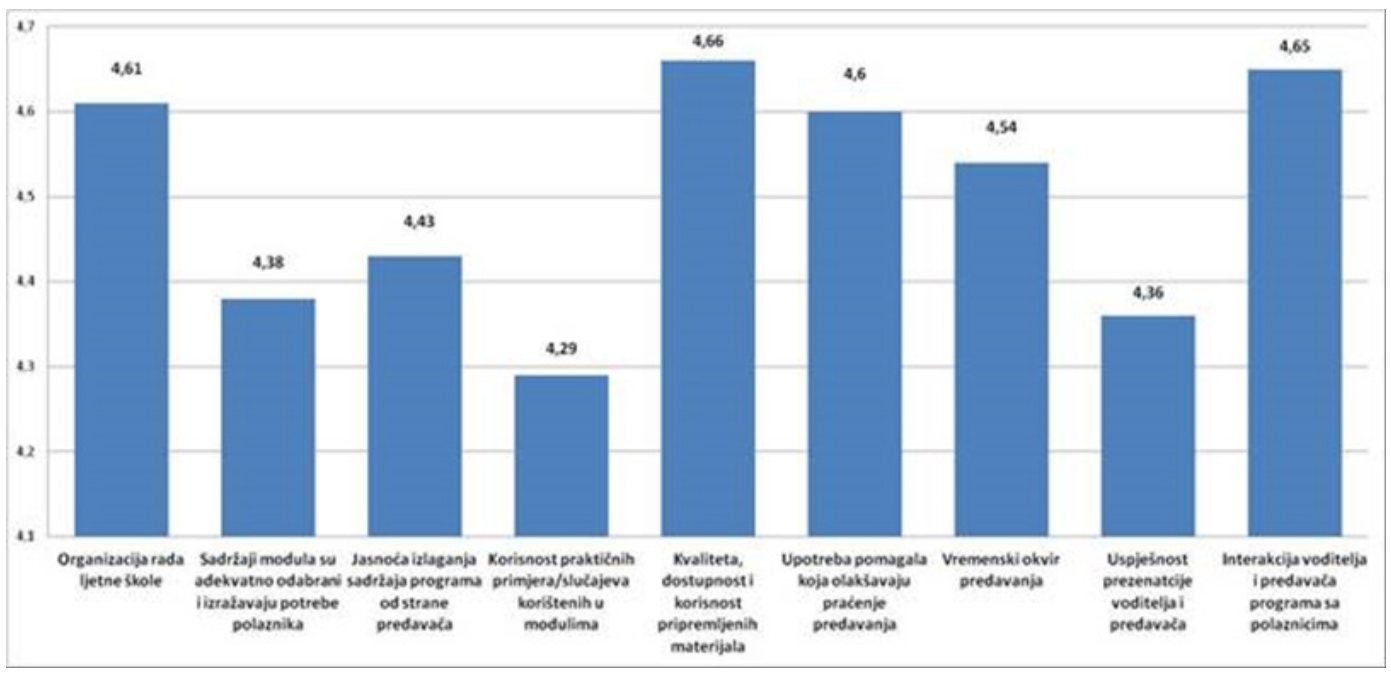

\section{International Summer School - Management in crisis situations}

The goal of this program was to train participants to understand organization in crisis prevention, preparation of activities and activity during a crisis as an important factor in institution decisions, local government and self-government bodies, as well as state government bodies. Partners in the realization of this program were the Federal Department of Civilian Protection, National Protection and Rescue Directorate of Croatia, Ministry of Security Bosnia and Herzegovina, State Investigation and Protection Agency - SIPA, Directorate for Coordination of Police Bodies of Bosnia and Herzegovina, Croatian Firefighters Community, city of Velika Corica and UG "Rendžer". Also, other partners in the program realization were the Faculty of Security Studies at the University of Belgrade, AAB College Pristina, "Logos centar" College Mostar, CEPS - Center for Business Studies High College and the Social Sciences Research Centre at the International Burch University ${ }^{62}$. The evaluation of the summer school, by a total of 83 participants, consisted of 9 questions that should evaluate the quality of organization and summer school program. The offered questions could be rated with 1 to 5 . The questions were related to the next summer school aspects: Summer school organization was rated with 4, 85; Module content was rated with 4,78; Content presentation quality with 4,81; Quality and availability of materials with 4,63; Presentation success of the lecturers with 4,38 , while interaction was rated with 4,80 . With a total

${ }^{62}$ http://criminaleast.fkn.unsa.ba/index.php/edukacija 


\section{Seccurity}

evaluation grade of 4,76 , we can conclude that all participants were extremely satisfied with the implementation of program content (graph No.2). This lifelong learning program was attended by 84 participants, of whom 30 were professionals and practitioners from organizations whose domain includers a broader security context, employees and volunteers from the non-government sector and 54 students from Croatia, Serbia, Kosovo and Bosnia and Herzegovina (graph No.3).

Graph No. 2- Lifelong learning program evaluation - International Summer School - Management in crisis situations

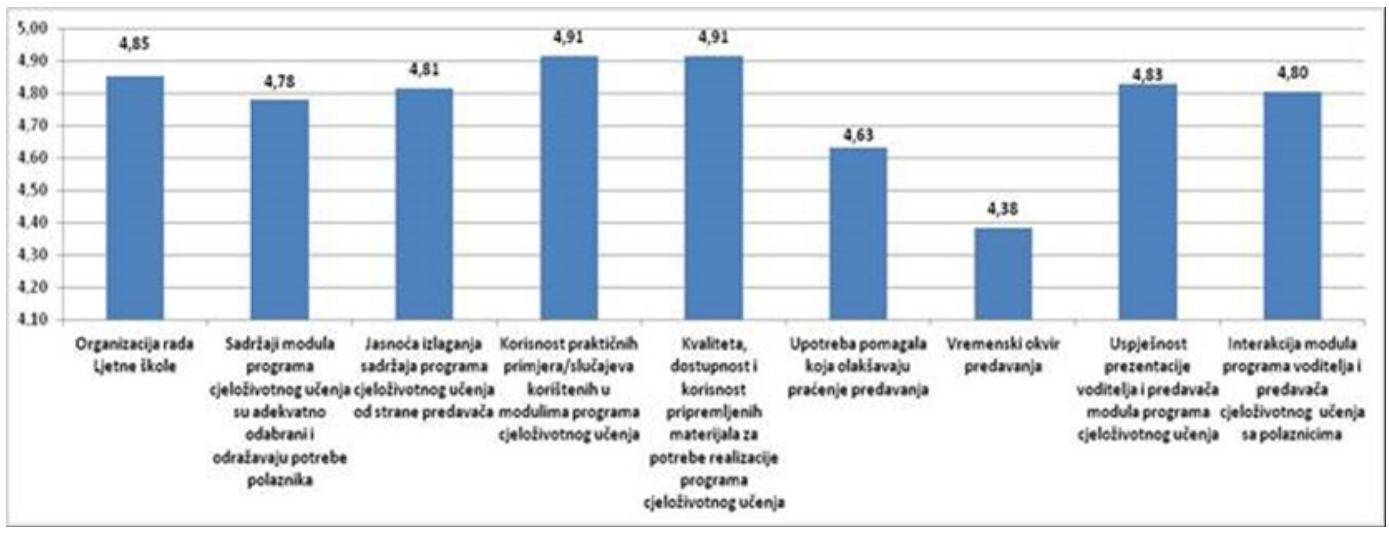

Graph No. 3 - Participant structure of the International Summer School - Management in crisis situations

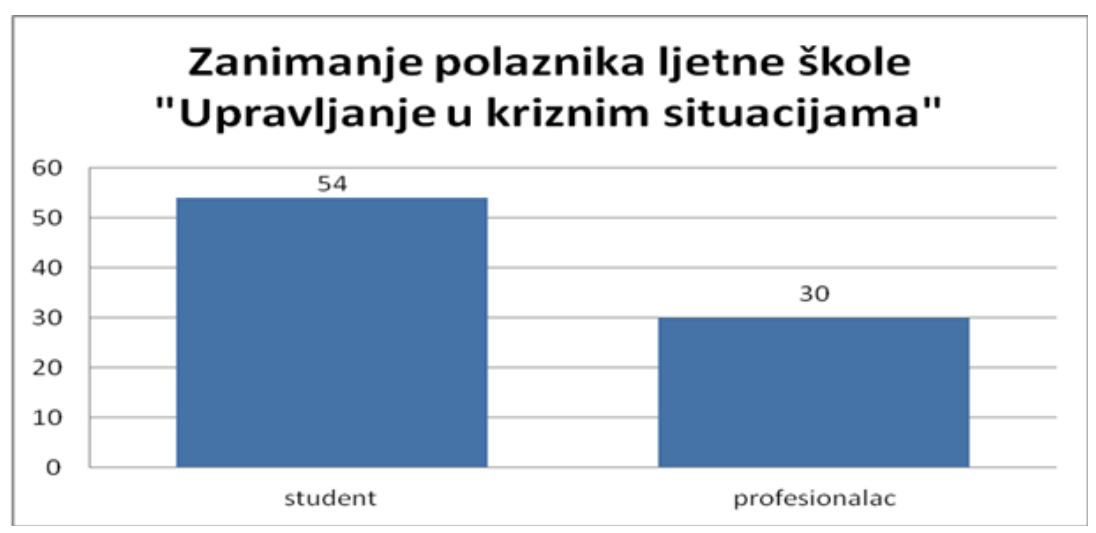

International Winter School - Corporative security and protection - The goal of this lifelong learning program, which was conducted by the Faculty of Criminal Justice, Criminology 
and Security Studies together with the University of Applied Sciences Velika Gorica from Croatia, was to gain new, and develop existing, knowledge and skills about the management of security and protection processes in public or private security sectors. The partners in realization of this program were: MICROSOFT Bosnia and Herzegovina, Agency for securing people and property DSC, Directorate for Coordination of Police Bodies of Bosnia and Herzegovina, Federal Department of Civilian Protection, Chamber of Commerce Sarajevo, JKP ZOI 84, Hotel "Maršal", IPA Sarajevo, Magazin a\&S Adria. Also, other partners in program realization were the Faculty of Mining, Geology and Civil Engineering at the University of Tuzla, CEPS - Centre for Business Studies High College ${ }^{63}$ Kiseljak. The undergone evaluation of the winter school from 42 participants consisted 9 questions which should rate the organization and program quality. The questions could be rated from 1 to 5 . They concerned the next aspects of the Winter School organization: Work organization of the winter school was rated with 4, 69; Module content selection with 4, 19; Content presentation clarity and quality with 4,63; Usefulness of practical examples with 4, 38; Quality and availability of materials with 4,66; Usage of teaching aids with 4,45; Timeframe with 3,97; Lecturer presentation success with 4,47, while interaction was rated with 4,63. With a total grade of 4, 45, we can conclude that participants were extremely satisfied with the content and its implementation (graph No. 4). This International Winter School - Corporative Security and Protection - was attended by 42 participants, 22 professionals from various organizations and 20 students from Croatia, Kosovo and Bosnia and Herzegovina (graph No. 5).

Graph No. 4 - Lifelong learning program evaluation - International Winter School - Corporative Security and Protection

Graph No. 5 - Participant structure of the International Summer School - Corporative Security and Protection

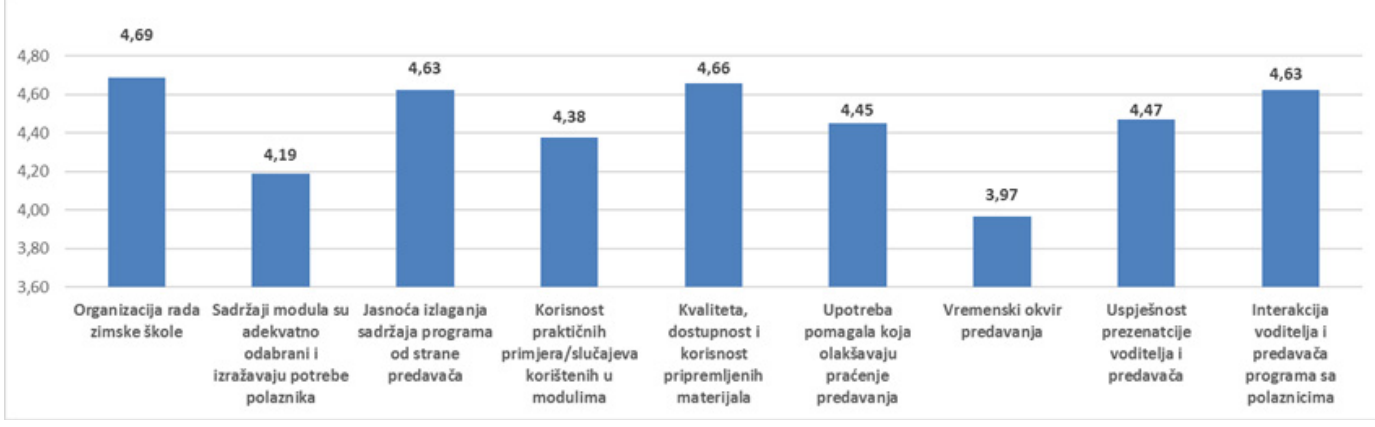

${ }^{63} \mathrm{http}: / /$ criminaleast.fkn.unsa.ba/images/pdf/Katalog_cjelozivotno_2017.pdf 


\section{Security}

\section{Zanimanje polaznika zimske škole "Korporativna sigurnost i zaštita"}

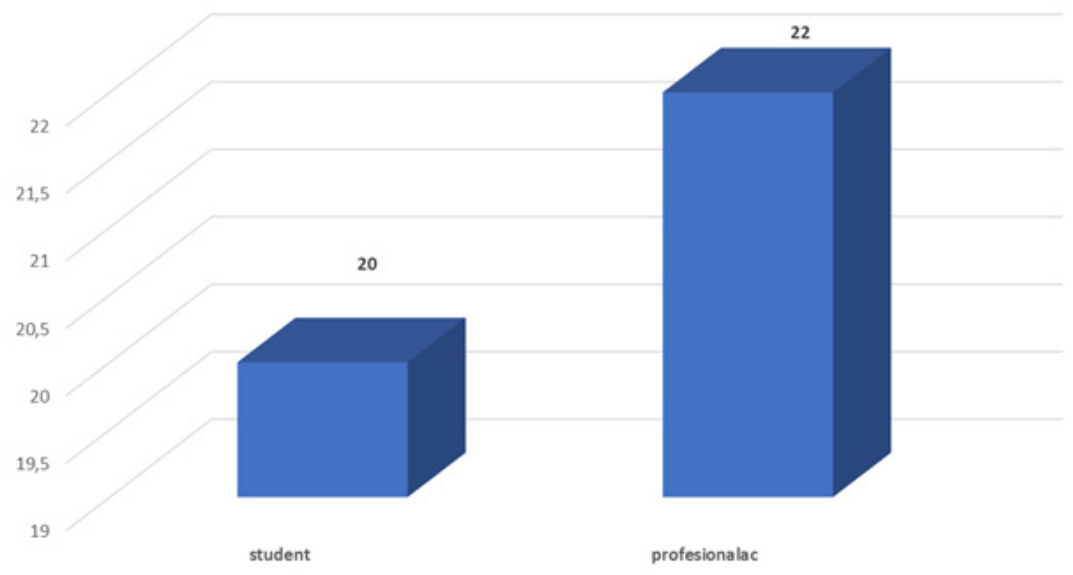

Summer School - Security in Educational Institutions - This summer school was realized in partnership with the Ministry of education, science, culture and sport of the Una-Sana Canton, Ministry of Interior of the Una-Sana Canton and RTV USK.

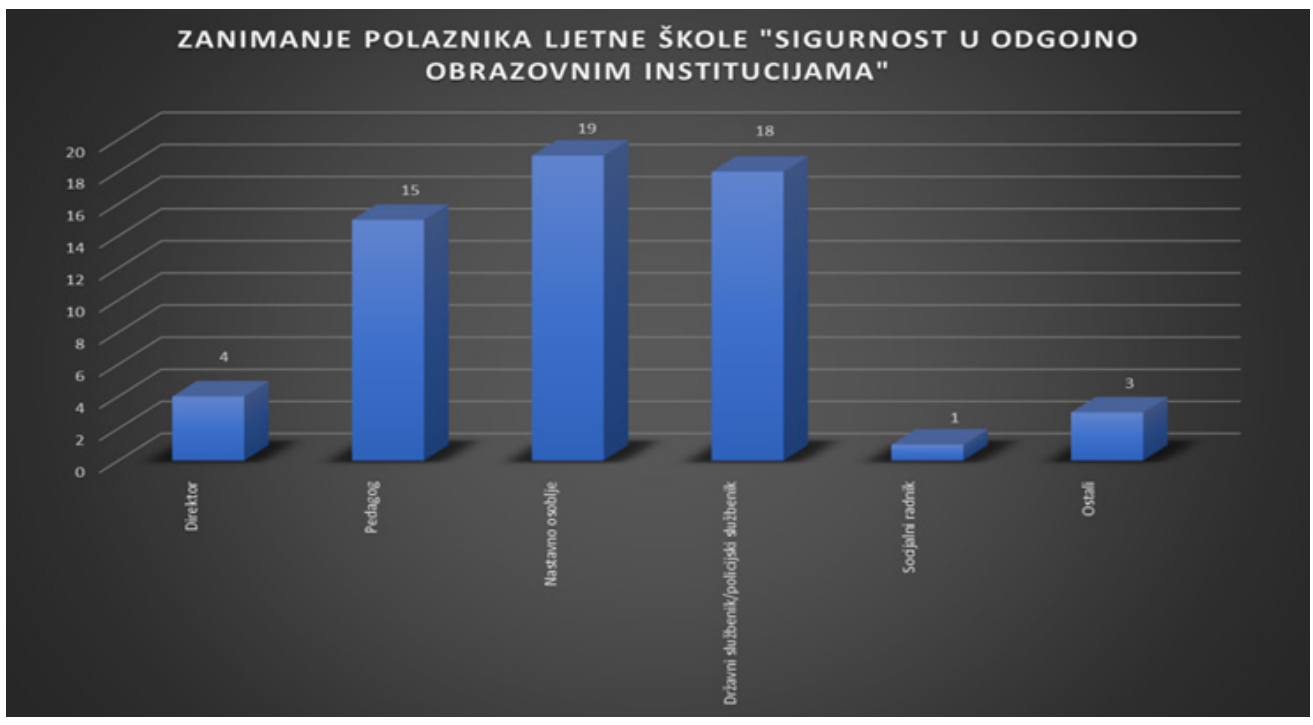


Academic staff of the Faculty, professors and associates, and the academic staff of our partner institution, the University of Applied Sciences Velika Gorica, together witch practitioners and experts, conducted an intensive five-day education for 61 participants from the Una-Sana Canton (principals, pedagogues, teachers and other employees from educational institutions, as well as employees from the Ministry of Interior of the Una-Sana Canton. The goal of this lifelong learning is to prepare participants to apply the gained knowledge in events of danger which could occur in spaces of permanent residence and children whereabouts, as well as young people in schools (yards, halls, playgrounds, classrooms, toilets), dangers for children and young people while performing their everyday school activities (teaching activities, extracurricular activities) , dangers with a broader scope and consequences (fire, earthquake, floods), dangers which may occur because of unfamiliarity, inexperience or inattention of children and young people, dangers for children which occur due to peer or other forms of violence through system familiarity, and the degree of critical school infrastructure management, risk evaluation, program solving, familiarity with child violence treatment guidelines in the educational sector - educational institutions, familiarity with providing first aid. ${ }^{64}$ The conducted program evaluation from 61 participants consisted from 9 questions which should rate the quality of organization and summer school program. The given questions could be rated from 1 to 5 . They concerned the next aspects of the Summer School organization: Work organization of the winter school was rated with 4,59; Module content selection with 4,61; Content presentation clarity and quality with 4,75; Usefulness of practical examples with 4,60; Quality and availability of materials with 4,55; Usage of teaching aids with 4,53; Timeframe of lectures with 3,4,53; Lecturer presentation success with 4,76, while interaction was rated with 4,54 . With a total grade of 4, 45, we can conclude that participants were extremely satisfied with the content and its implementation (graph No. 6). This International Winter School - Corporative Security and Protection - was attended by 61 participants, 4 school principals, 15 school psychologists, 19 teachers, 18 police officers, 1 social worker, and 3 others (graph No. 7).

Graph No. 6 - Lifelong learning program evaluation - Summer School - Security in Educational Institutions

Graph No. 7 - Participant structure of the Summer School - Security in Educational Institutions

Summer School - Crime Scene Processing - This summer school was realized in partnership with the Ministry of Interior of the Una-Sana Canton and Ministry of Interior of the Tuzla Canton, and was intended for 20 employees of the Police Administration USK and 20 employees of the Police Administration TK. The education was conducted by academic staff of the Faculty of Criminal Justice, Criminology and Security Studies at the University of Sarajevo, together with experts from law enforcement agencies in Bosnia and Herzegovina. The goal of this lifelong learning

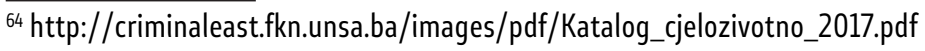




\section{Security}

program was to train the participants for understanding, organizing, preparing and activity during procedures related to proceedings in crime scene processing, and to be able to apply the gained knowledge concerning proceedings in specific kinds of evidence (biological samples, papillary lines and electronic evidence). ${ }^{65}$ The conducted program evaluation from 61 participants consisted from 9 questions which should rate the quality of organization and summer school program. The given questions could be rated from 1 to 5 . They concerned the next aspects of the Summer School organization: Work organization of the winter school was rated with 4,30; Module content selection with 4,37; Content presentation clarity and quality with 4,60; Usefulness of practical examples with 4,50; Quality and availability of materials with 4,20; Usage of teaching aids with 4,15; Timeframe of lectures with 3,70; Lecturer presentation success with 4,45, while interaction was rated with 4,10 . With a total grade of 4,25 , we can conclude that participants were extremely satisfied with the content and its implementation (graph No. 8).

Graph No. 9 - Lifelong learning program evaluation - Summer School - Crime Scene Processing

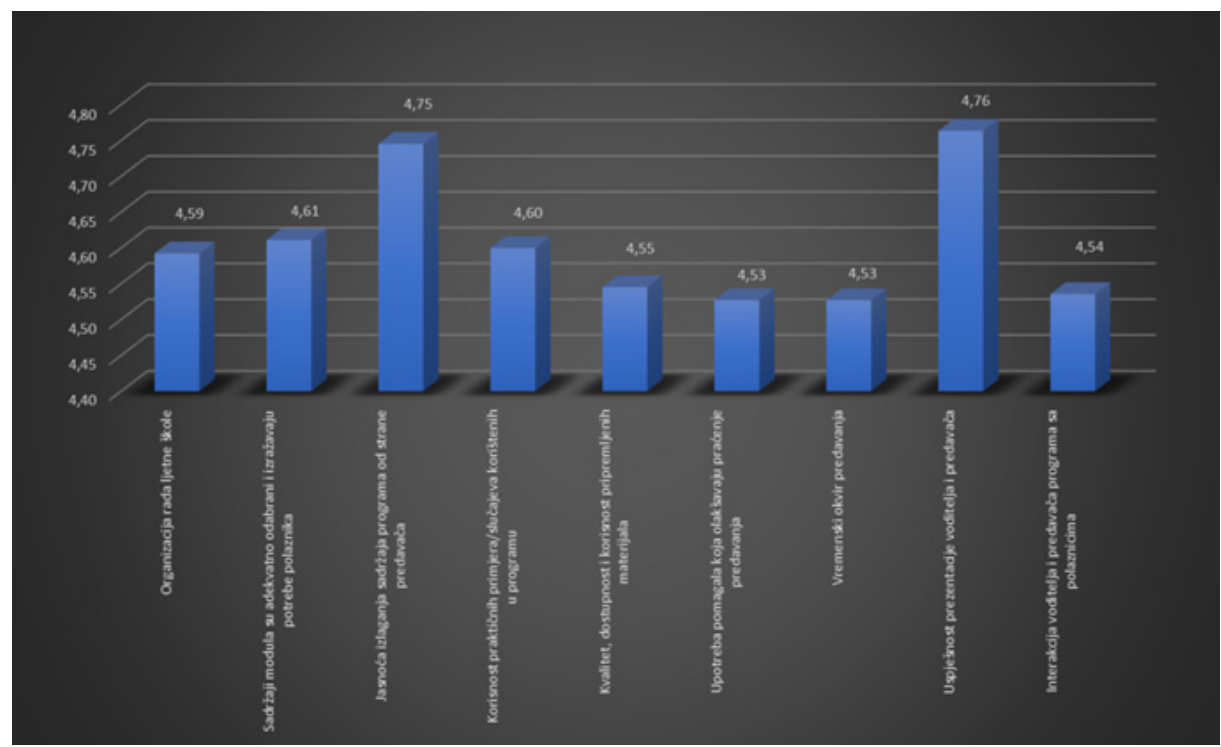

${ }^{65}$ https://www.summerschool.ba 


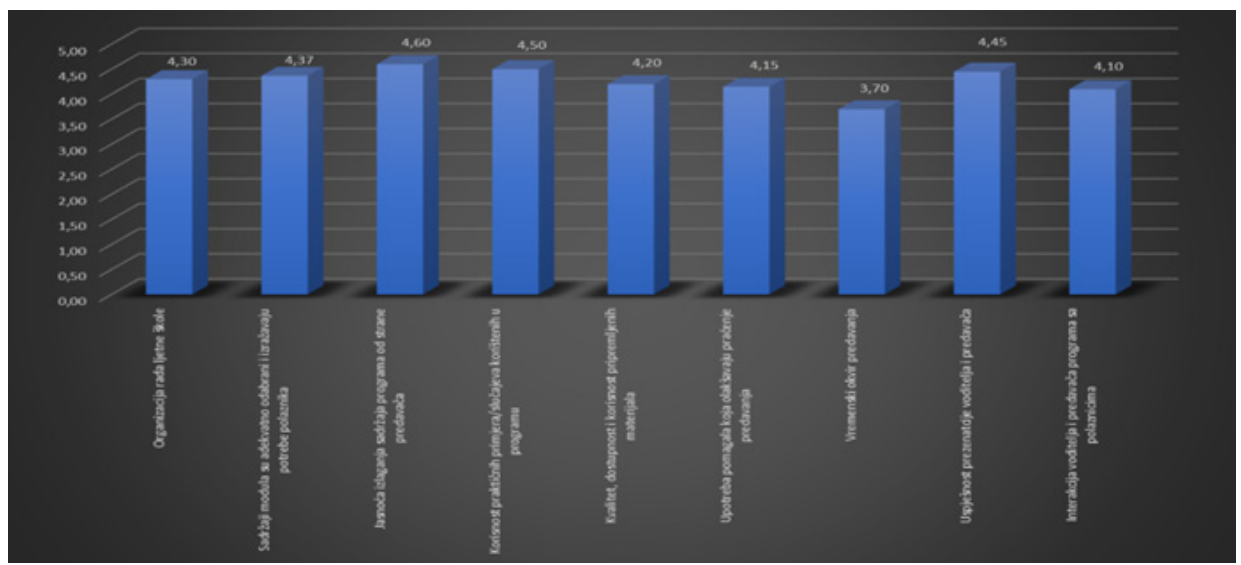

\section{Conclusion}

Sustainability of a lifelong learning program depends on financial and administrative sustainability, and they represent one of the key factors to ensure the program implementation continuity. In order to achieve financial sustainability of a continuous education, or lifelong learning, it is necessary to develop interdisciplinary lifelong education programs in partnership with other higher education institution, government, non-government and economic sectors from Bosnia and Herzegovina and region, through forms of international summer and winter schools. This way we would provide the exchange of knowledge, experience and good practices, as well as teachers and students together with experts and professionals. The sustainability of a lifelong education program is not possible without commercialization and fundraising from local or state budgets or economic subjects. In order to develop lifelong learning programs directed towards social needs and curricular education reforms, it is necessary to influence competent authorities on state level to administratively approve such education programs, as well as retraining of state administration employees. With this acyclic academic programs of lifelong learning - winter and summer schools - the Faculty of Criminal Justice, Criminology and Security Studies at the University in Sarajevo wanted to influence the increase in capacity of existing skills and competences, and, before all, of our first, second and third cycle students, alumni, as well as other interested summer and winter school participants, who want to train themselves to master the process of management in events of crises through the understanding of their sources and consequences, along with their causeeffect relationship. Additionally, the winter and summer school goal, as a lifelong education form, is to train participants to understand process organization within the crisis management cycle to be able to professionally join mentioned processes within competent authorities dealing with such areas. 


\section{Literature:}

1. Coombs, P. H. (1968). The World Crisis in Education. New York: Oxford University Press.

2. Dohmen, G. (1996). Lifelong Learning: Guidelines for a modern education policy. Bonn: Federal Ministy of Education, Science, Research and Technology.

3. Korajlić, N., Toth, I., Ahić, J., Hadžikadunić, A., Muratbegović, E. (2016). Katalog programa cjeloživotnog učenja "Upravljanje u kriznim situacijama" i "Smjenice za postupanje u slučaju nasilja nad djecom u Bosni i Hercegovini". Fakultet za kriminalistku, kriminologiju i sigurnosne studije, Univerzitet u Sarajevu. Institut za kriminalistiku, kriminologiju i sigurnosne studije "CriminalEast". ISBN 978-9958-613-74-6. Način dostupa (URL): http:// criminaleast.fkn.unsa.ba/. - Nasl. s nasl. ekrana. - Izvor opisan 10. 05. 2016.

4. Korajlić, N., Toth, I., Ahić, J., Hadžikadunić, A., Muratbegović, E. (2016). Katalog programa cjeloživotnog učenja "Međunarodna zimska škola - korporativna sigurnost i zaštita" i "Ljetna škola - sigurnost u odgojno obrazovnim ustanovama“. Fakultet za kriminalistku, kriminologiju i sigurnosne studije, Univerzitet u Sarajevu. Institut za kriminalistiku, kriminologiju i sigurnosne studije "CriminalEast". ISBN 978-9958-613-92-0. Način dostupa (URL): https://www.simplebooklet.com/cjelozivotno. - Nasl. s nasl. ekrana. - Izvor opisan dana 24. 3.2017.

5. Matković, I., Poljak, V. (1989). Samoobrazovanje. Pedagoška enciklopedija. Beograd: Zavod za izdavanje udžbenika, Zagreb: IRO Školska knjiga, Sarajevo: Zavod za udžbenike i nastavna sredstva, Titograd: Republički zavod za unapređivanje vaspitanja i obrazovanja, Novi Sad: Zavod za izdavanje udžbenika.

6. Međunarodna standardna klasifikacija obrazovanja (2000). Zagreb: Državni zavod za statistiku. (Izvornik: International Standard Classifi cation of Education. 1997. Paris: UNESCO.)

7. Pastuović, N. (2008). Cjeloživotno učenje i promjene u školovanju. Odgojne znanosti. Vol. 10, br. 2, 2008, str. 253-267. Zagreb.

8. Strategija obrazovanja, znanosti i tehnologije. Cjeloživotno učenje i obrazovanje odraslih. Zagreb, 16. rujna 2013.

9. http://ec.europa.eu/education/policies/2010/doc/comm481_en.pdf (visited on 28.05.2018)

10. ht t p: / / e ur-ex. e uropa. eu / LexUriServ/LexUriServ. do? uri=COM:2001:0678:FIN:EN:PDF(visited on 28.05.2018)

11. h t t p: / / e ur-I ex. e uropa.e u / LexUriServ/LexUriServ. do?uri=0J:C:2002:163:0001:0003:EN:PDF(visited on 28.05.2018) 